Santa Clara University

Scholar Commons

Economics

Leavey School of Business

$8-20-2006$

\title{
Official Representations of the Nation: Comparing the Postage Stamps of Sudan and Burkina Faso
}

Michael Kevane

SantaClara University, mkevane@scu.edu

Follow this and additional works at: http://scholarcommons.scu.edu/econ

Part of the Economics Commons

\section{Recommended Citation}

Kevane, Michael, Official Representations of the Nation: Comparing the Postage Stamps of Sudan and Burkina Faso (August 20, 2006). Available at SSRN: http://ssrn.com/abstract=1115505 or http://dx.doi.org/10.2139/ssrn.1115505 


\title{
Official representations of the nation: Comparing the postage stamps of Sudan and Burkina Faso
}

\author{
Draft: Version 2.1 \\ August 20, 2006 \\ Please do not cite (contact author for latest draft) \\ Michael Kevane \\ Department of Economics \\ Santa Clara University \\ Santa Clara, CA 95053 \\ 408-554-6888 \\ 408-554-2331 (fax) \\ mkevane@scu.edu
}

\begin{abstract}
An analysis of the imagery on postage stamps suggests that regimes in Burkina Faso and Sudan have pursued very different strategies in representing the nation. Sudan's stamps focus on the political center and dominant elite (current regime, Khartoum politicians, and Arab and Islamic identity) while Burkina Faso's stamps focus on society (artists, multiple ethnic groups, and development). Sudan's stamps build an image of the nation as being about the northern-dominated regime in Khartoum (whether military or parliamentary); Burkina Faso's stamps project an image of the nation as multi-ethnic and development-oriented.
\end{abstract}




\section{Introduction}

The sovereign state of Sudan, as a stamp-issuing entity, has chosen over the past fifty years to not honor on its postage stamps any person from the southern region of the country. This is a sharp fact that cuts through the rhetoric that the dominant northern elite deploys to ward off separatist sentiment in the south. This rhetoric is that the Sudan is a land of many peoples, but one country, with a shared hybrid Afro-Arab identity. If that is the case, then why have there been no southern, African heroes on the stamps of the country? Consideration of the images on the postage stamps of Sudan reveals another fact. In contrast with many other African states, Sudan issues shockingly few stamps that celebrate the multi-cultural make-up of the country. Many African states regularly issue postage stamp series that represent cultural icons and images from major culture groups; Sudan has done so only once (and ironically under the regime considered by most to be least tolerant of difference).

This paper compares the imagery on postage stamps of Sudan and Burkina Faso. Burkina Faso's imagery offers a counterpoint to that of Sudan, a "what might have been." The categorization and coding suggest that the two countries, through repeated regimes, have produced very different themes. Burkina Faso's political regimes have placed high value on messages of multicultural tolerance, while Sudan's political regimes emphasize a single Arab, Islamic, and northern Sudanese identity for the country. No student of Sudan's colonial and post-colonial history will be surprised by this result (see, e.g. Sharkey 2003). But they may find it useful and stimulating. The content analysis of postage stamps offers striking and irrefutable complementary evidence of the non-inclusive character of Sudanese regimes since independence. There are other quasi-objective indicators of regime strategies that might also be analyzed (street names, media content, public statuary, etc). There is a clear lacuna of sociological analyses of the impact of state-produced imagery in Sudan and the civil society response. Also lacking, in the corpus of Sudan studies, are analyses of the icons and songs of the Southern People's Liberation Army (SPLA), and the role of images of "Dr. John" himself as symbols of the aspirations of people in the South, or at least those the SPLA wants them to have.

A number of researchers have analyzed postage stamps in their efforts to pattern representational strategies of regimes. A recent issue of African Arts was devoted to the imagery on African postage stamps (Adedze 2004a; Adedze 2004b; Levin 2004; Posnansky 2004). Cusack (2003), in his analysis of the stamps of Lusophone Africa, argues that, "stamps are carriers of potent images of the dominant ideologies of the state..." Baron (2005, pp. 74-77), to take another example, sees in early images of peasant women on postage stamps of Egypt confirmation of the ascendancy of a feminization of nationalism, of Egypt as a woman.

There are also analyses from other parts of the world. Jones (2004) analyses the imagery celebrating scientists on stamps to show that England, France and Germany have had different representations, in ways that perhaps reflect distinct social valuation of science and scientists. Brunn (2001) reviews the first stamps of newly independent nations of Central Asia and Europe, finding that symbols of statehood (flags and coats of arms) trumped ideological messages. Raento and Brunn (2005), in an analysis very similar to that conducted here, trace the imagery on Finnish postage stamps over the period 1917-2000. Other recent papers analyze the images on stamps of France, Ireland, South Africa, Latin America, and Japan. (Child 2005; Lauritzen 1988; McQueen 1988; Newman 1989; O'Sullivan 1988; Reid 1984; Scott 1992). 
The paper proceeds as follows. Section 2 offers historical background on each country, illustrated by postage stamps. Sections 3 and 4 present the method and results of a categorization and coding of stamps, enabling analysis of how the major themes on postage stamps have evolved over time as regimes succeed each other. Section 5 offers some concluding reflections.

\section{Brief history of Sudan and Burkina Faso illustrated by postage stamps}

For centuries, political entities centered on the Nile raided for slaves and extracted resources from Sudan's population. These entities ebbed and flowed, to eventually coalesce into a kingdom located in Sennar on the Blue Nile. In 1821, an Egyptian expedition organized by Mohammed Ali invaded the region. The Turkiyya, as the next six decades came to be known, forged a bureaucratic state centered in Khartoum, capable of projecting power through much of the territory of contemporary Sudan. That power continued to be used for raiding and resource extraction. A revolt led by Mohamed Ahmed, the Mahdi, crushed the Egyptian and British forces in 1885 (the battle was commemorated on a stamp in 1985, and Mohamed Ahmed in 2003). The successor regime, known as the Mahdiyya, employed some of the clerks and literate functionaries of the earlier period, but attempted to create an Islamic political entity to guide the community of Muslim believers, the umma. The spirit of the regime was not nationalist, in the European sense. British-led forces destroyed the Mahdiyya in 1898 (the defeat was commemorated on a stamp in 1998) and established colonial rule, the Condominium. The British eventually settled on a Closed District policy for the south, indirect rule through Native Administration policy for rural areas in the north, and bureaucratic administration of towns, ineluctably cultivating an educated elite of northern Sudanese who inherited power at independence in 1956.

Burkina Faso likewise had centralized kingdoms that strategically used insecurity on the periphery as opportunity for predation. The Mossi Empire, as Delobsom (1932) labeled the political and cultural alliance of four kingdoms, was probably founded in the 1300s and survived, as a political entity, conquest by the French in 1898. Originally administered as part of French West Africa (Soudan), the French created in 1919 the colony of Haute Volta, largely coterminous with the Mossi Empire and the northern reaches of the kingdom of Kong. The colony was suppressed in 1932 and chopped up among three other administrative regions, but was reanimated in 1947, became a republic in 1958 and then independent in 1960. It was renamed Burkina Faso in 1983.

Neither colonial power saw fit to create, through images on postage stamps, an iconography of nationalism. Colonial stamps of both countries consisted almost entirely of innocuous images of bucolic tribal life, with generic and non-identifiable scenes. The Sudan Political Service stuck to its famous 'camel postman' design. There were only two exceptions. In 1935 a series honored Charles Gordon, the British officer defeated by the Mahdi in 1885, and in 1951 an inclusive series showed people and scenes from all corners of Sudan. Colonial Haute Volta did not issue its own stamps, instead using issues from the region of French West Africa. Only two of these stamps were specifically designated with imagery from Haute Volta. One celebrated the construction of the railroad reaching Ouagadougou in 1956. Another honored the Mossi emperor, the Mogho Naba, in 1958. Apparently, the colonial authorities wanted to reward and flatter the Mogho Naba for opposition to the regional ambitions of Félix HouphouetBoigny's Rassemblement Démocratique Africain party in Cote d'Ivoire (Adedze 2004a). The 
stamp shows the Mogho Naba’s face over a map of the colony: “This is your country,” the stamp seems to say.

After independence, both parliamentary regimes quickly succumbed to military coups, Sudan in 1958 and Haute Volta in 1966, and neither country has had stable democratic governance since.

Early stamps of Haute Volta featured large portraits of the first two pre-independence presidents, and then at full independence in 1960 a well-designed stamp with flag, village and peasant farmers was issued. In 1965 President Maurice Yaméogo, who had fashioned a singleparty regime, featured a large portrait of himself on a stamp; he was ousted within a year. General Sangoulé Lamizana, then ruled Haute Volta from 1966 to 1980, when he in turn was ejected in a bloodless coup. Ironically, Lamizana's only appearance on a stamp was to commemorate the visit of Pope John Paul II in 1980, just before he lost power. Junior officers took over, notably Thomas Sankara who ruled from 1983-87 and whose lasting innovation was to rename country Burkina Faso. The change itself reflected the multi-cultural inclusiveness typical of regimes in the country: Burkina means "integrity” in the Moré language of the Mossi, while Faso means "father's house” in the Dioula language, and the citizen identifier Burkinabè uses the Peul language suffix "bè" to indicate a "person of." Sankara was also prominently featured on a stamp commemorating the first anniversary of his regime. The stamp featured a typical heroic-sized portrait of the president in front of "the people." In 1987, second-incommand Blaise Compaoré had Sankara and other members of the regime killed or ousted and he assumed sole control of the country. Compaoré has civilianized his rule, and after having the national constitution amended he was re-elected for a third term as president in 2005. Compaoré has not appeared on any stamps.

Sudan began independent stamp-issuance with an uninspired rendition of map and national emblem, followed by a stamp commemorating the Arab Postal Union. The military regime followed with a stamp showing a farmer shaking hands with an infantryman, followed by a stamp commemorating the opening of a new Arab League building in Cairo. So the first four stamps were about the political regime and state (not the people), and the Arab identity of the country. Southern military officers, who rebelled in 1955 fearing the worst from the northern elite, would have had no reassurances in the stamps of the first decade. The Arab League was featured again in 1962, 1967 and 1972, and the Arab Postal Union again in 1964, and the PLO in 1967. Cultural icons from the northern pre-Islamic period appeared on six stamps, stemming from world-wide interest in salvaging archeological items from the Aswan High Dam's lake. These were belated tips of the hat to the Nubian population of the northern region, whose homelands were destroyed by the dam. Africa-wide institutions first appeared with a stamp honoring the African Development Bank in 1969 and then the African Postal Union in 1972. One might say that the Arab to Africa ratio was 7:2 by 1972 .

The military regime of Ibrahim Abboud lasted until 1964, when popular urban protests led to a bloodless transition to civilian rule in the north. A few students killed in a protest, one of whom, al-Gurashi, was honored in a 1965 stamp. The parliamentary regime survived only five years but during this time issued a striking set of stamps featuring portraits of prominent political leaders of the pre-independence period including two from the Mahdi family, whose scion, Sadiq al-Mahdi, was Prime Minister. Those honored were El Siddig al Mahdi, Mubarak Zaroug, Abdullahi el Fadil al Mahdi, Mohammed Nur al Din and Ahmed Yousif Hashim, and Mohamed Ahmed al Mardi. 
Colonel Gaafar Nimeiri took power in a coup in 1969, and put himself on a stamp in heroic pose, in front of "the people" in 1970. (An interesting sidelight of philatelic history, to my knowledge not researched, is that the first issue of the set of stamps was withdrawn on the day of issuance, and then re-issued several months later. The only difference, apparently, other than a slight change in the placement of the denomination, is the skin-tone of Nimeiri and the background persons; in the original they are shaded, in the reissue they are white.) Nimeiri presided over, but then shattered, a ten-year peace with the south. The civil war re-ignited in 1983, and continued through 2005. A bloodless civilian uprising ousted Nimeiri in 1985, but the parliamentary regime that followed lasted only four years and escalated the civil war. A sign of the disorganization of the regime (close to what political scientists call anocracy), only six stamps or series were issued over the period. One represented fishing (in Sudan!) for World Food Day. In 1989, military units working with the National Islamic Front seized power and have held power until the present. Colonel Omar al-Beshir and NIF ideologue Hasan al-Turabi jointly ruled until 1999, when al-Beshir bested al-Turabi in a struggle for power. Al-Beshir escalated the war in the south, pushing proxy militias to commit ethnic cleansing and developing an ideologically correct paramilitary force known as the Popular Defense Forces (PDF) to shadow the army, but then went on to sign a peace agreement with the southern rebels under John Garang in 2005. Al-Beshir was unable to control in 2003 a smaller rebel movement in Darfur in western Sudan, and unleashed proxy militias whose wanton destruction led to human catastrophe of hundreds of thousands dead and millions displaced.

The two countries have had very different paths, Sudan with a 50 year long civil war in the south and long-simmering and finally erupting war in western Sudan, while Burkina Faso has had no significant incidence of ethnically or regionally-based civil strife. It seems worth inquiring, then, whether the content of their postal stamps sheds light on the different strategies of national representation pursued by political elites.

\section{Coding postage stamps}

Quantitative measurement of the imagery on postage stamps has several virtues. Such quantification permits a subtle, complex and continuous measurement of regime strategy, since typically numerous stamps are issued in every year. Imagery on stamps varies quite a lot, since it is relatively inexpensive to design new images: the regime simply requests stamp designers to produce a new image that can be incorporated onto stamps and distributed throughout the country.

Decisions have to be made when coding the imagery on stamps, even before arriving at a smallish number of categories to be used for grouping the wide variety of images and messages. These decisions arise from four sources of complexity in the kinds of stamps produced by countries: (1) some stamps are intended for the collectors market; (2) some stamps have different physical properties from the ordinary perforated, gummed stamps, properties that make them more or less suitable for use on letters; (3) the quantities produced and usage of stamps vary with the images on the stamps, in perhaps predictable ways; (4) and many stamps are issued in series rather than as stand-alone images. These four characteristics of stamps- collectability, properties, quantities, and series- have to be addressed in coding.

First, many countries issue stamps that are aimed at the philatelic market, and are not intended for domestic use. In 2004, about 70 countries of the world were clients of the InterGovernmental Philatelic Corporation (IGPC), a private stamp designing and marketing firm. This firm works with client countries to produce stamps that are desired by collectors who 
collect by the images on stamps (known as 'topical collectors'). These collectors, mostly based in the United States, seem to prefer certain kinds of images: celebrities (Lady Di, Mother Theresa, the Pope); domesticated animated (cats and dogs); wild flora and fauna; space exploration; Boy Scouts; etc. Fortunately, most collectibles are quite easy to spot: they have nothing to do with the country issuing the stamps.

Second, many countries issue a variety of kinds of stamps, including stamps with perforations, imperforated stamps, souvenir sheets with perforated stamps and souvenir sheets with imperforated stamps. As the categories suggest, some of these stamps are explicitly intended to be souvenirs. In the coding presented here, all stamps that are explicitly issued as souvenir sheets are excluded.

Third, quantities produced of stamps vary with the images on the stamps. Many countries limit printing runs of more fancy 'commemorative' stamps (which cost more to design and print), and encourage use of 'regular” issues for domestic postal service. Many countries also issue separate stamps for overseas airmail service. These stamps are less likely to be used on domestic mail. Unfortunately, there seems to be no easily accessible data on number of stamps sold (or even printed) for each amount. Many countries confronting inflation routinely surcharge old stamp issues, sometimes decades after their first issuance, suggesting that national postal administrations sometimes retain substantial stocks of stamps that, for one reason or another, did not get used when originally issued. Stamps also vary in denomination, with regular postage stamps used for ordinary letters presumably more common than other stamps (especially those of larger denomination), but again, in many African countries it is not uncommon to find regular mail using four or five smaller denomination stamps. For the analysis presented here, surcharged stamps are not counted, and no adjustments are made for differing denominations. Only regular issues, and not airmail or official stamps, are coded.

Fourth, countries usually issue stamps in series. There may be a set of five stamps issued to commemorate local buildings. Sometimes these sets consist of stamps with the same images, or images that are variations of a common image but with different colors and denominations. For the analysis presented here, stamps are only counted if they have a separate and novel image. Different denominations of the same stamp image are counted only once.

\section{Stamp imagery of Burkina Faso and Sudan}

The goal in coding the imagery on stamps is to classify stamps into a discrete number of mutually exclusive categories. Three very broad umbrella categories have been used for this analysis: (1) stamps for the philatelic collectors market; (2) internationalist stamps; and (3) and national-oriented stamps. National-oriented stamps are further categorized according to their emphasis on twelve themes: Christianity, Colonial power, Commemoratives and political, Development, Single ethnic group, Icons of the nation, Multi-ethnic, National political person, National non-political person, Nature, panAfrican, panArab and panMuslim, Presidents, Women. Stamps are coded using a first-level analysis: the image or statement on the stamp is taken at face value, and possibly hidden or subtle meanings are not coded. A picture of the President is taken to be a stamp about the President, and if the stamp designer has given the President a too-large ear to mock him, that is not coded. Some interesting studies use formal semiotic methods to code stamps for one country for a limited period of time, and to codes flags and national anthems according to formal criteria, but this is perhaps impossible with the large number of postage stamps that would need to be coded (Cerulo 1995; Scott 1995). 
The categories and national-oriented subcategories are explained more fully in Table 1, which also presents the numbers and percentages for each category for Sudan and Burkina Faso, coded over the period 1960 through 2003. Figure 1 shows how the number of stamps issued per year varied over the period. As can be seen, Sudan has produced almost no collector stamps, and in general has produced a small number of stamps-only 208 over 40 years, compared with 936 for Burkina Faso. Even in the non-collector categories, the imagery output from Burkina is double that of Sudan. Among national-oriented stamps, there are sharp distinctions, as noted in the introduction. Burkina Faso has produced large numbers of multi-ethnic series of stamps. Sudan has not. Burkina Faso has also produced a much higher share of development-oriented stamps. Sudan, by contrast, has produced a higher share of stamps depicting national icons, commemorating political events (especially regime anniversaries and historical events), celebrating the Arab League and Islamic icons, and honoring political figures (mostly during the second parliamentary period in the mid-1960s).

Figure 2 shows how the broadest categories have changed over time, for political regime in each country. Remarkable is how for both countries the percent of national-oriented stamps has been declining. Collector stamps have been rising steadily for Burkina Faso, and only became significant for Sudan for the current military regime. The current Sudanese regime also sharply cut the number of stamps celebrating international organizations and activities. For the various national-oriented categories presented, it is striking how much more variable Sudan is across regimes, compared with Burkina, where percentages change slowly across regimes.

Figure 3 presents the same numbers in a different way, aggregating some of the categories into four categories: political (commemoratives, political persons, presidents); civil society (development, women, non-political persons); ideology (icons, panAfrica, panArab and panIslam); and multiethnic. The radar chart shows the percent of stamps in each category for each regime. So Sudan has six regimes, while Burkina has four regimes. At this broader level of aggregation, there is striking consistency across regimes: Sudan's stamps are sharply skewed towards ideological and political stamps; Burkina's stamps sharply skewed towards multiethnic and civil society.

At a broad level Sudan's stamps focus on the political center (regimes, Khartoum politicians, and Arab and Islamic identity of the country) while Burkina's stamps focus on society (artists, multiple ethnic groups, and development). Sudan's stamps build an image of the nation as being about the northern-dominated regime in Khartoum (whether military or parliamentary); Burkina's stamps project an image of the nation as multi-cultural and development-oriented.

\section{Conclusion}

Political regimes that represent states in sub-Saharan Africa, as elsewhere, use iconography to evince emotion and sentiment. Citizens and subjects respond, of course, with icons of their own making. But the images individuals create are not always made under conditions of their own choosing, and state icons may display a disproportionate power in their effects. This power enables states to disproportionately initiate and capture the space of thought, and counter private responses.

Part of the power of states comes from the massive resources, reach, and organization available in its image production. States can mandate an image of the president in every office, a national flag on every postage stamp, the national emblem on every piece of currency, national colors on the airline, statuary in the roundabouts, and music on the airwaves. Few other 
organizations can compete: ethnic groups may be able to produce music, masks, clothing, and dances; churches and mosques use their rituals, architecture, and vestments; opposition groups may carefully choose a color and symbol for public manifestations. But as these examples suggest, their resources, reach, and organization are limited compared with that of most states. Another part of the power of the state flows from an international order that naturalizes states as expressions of the will of the people. The international legitimation of states adheres even to illegitimate states, making their icons have unwarranted effects. Ubiquitous and ordinary, postage stamps include themselves in the repertoire of everyday construction of national identity (Billig 1995; McCrone 1998). Appeal to authority is never sufficient to justify intellectual effort, but in arguing the case it is useful to recall Albert Hourani's analysis of the emergence of nationalism in the Arab world. The new spirit, according to Hourani (1983, p. 350), "was symbolized by the change in postage stamps, which no longer showed mosques or sphinxes or kings, but workers and peasants in heroic attitudes, shaking their fists at fate.”

Excessive power and routinization banalizes and tempers the power of state iconography. Licking a stamp and handling the face of the sovereign on currency may make too intimate the majesty of power. A repressed community of the arts encourages the least imaginative to rise to positions of authority in the image-making machinery of a state; the results are often laughable. A lively opposition may cleverly make mockery of state images. Intelligent citizens encourage others to pierce the hubris of power.

Inquiring into the effects and meanings associated with state iconography thus suffers from fundamental epistemological questions about translating and measuring popular understanding. Does the image of the President in leopard skin fez instill fear and abjection, or a derisive and dismissive grunt in the ordinary citizen? When the Islamic regime of 1989 Sudan ordered the painting of all commercial doorways in the pale green of Islam, did this encourage piety and respect for the regime, or compliant insolence? When the revolutionary regime of Thomas Sankara in Burkina Faso rebaptised a main street as Avenue Nkrumah, did the residents of Ouagadougou give a hooray for pan-Africanism or roll their eyes at the excesses of youth? More generally, have sentiments and actions inspired by national icons, whether of fear, derision, or compliance, engendered other common sentiments or inspired other common actions? Is the commonality extended to many through and reinforcing their identity as national citizens subject to or participating in a state? Or does the commonality disintegrate or exclude some from national identity?

A small, modest paper comparing the imagery on postage stamps of Sudan and Burkina Faso cannot answer these questions, but the questions that are addressed here are motivated by these larger questions. One thing is clear: the sovereign and internationally recognized state of Sudan has rationalized its long war against the SPLA by mocking rebels as malcontents overly distrusting of northern good intentions. The imagery on the stamps issued by Khartoum suggests the southerners are fully justified in their suspicions of a hegemonic project by the north. 


\section{References}

Adedze, Agbenyega. "Commemorating the chief: the politics of postage stamps in West Africa." African Arts (2004a).

Adedze, Agbenyega. "Re-presenting Africa: Commemorative Postage Stamps of the Colonial Exhibition of Paris." African Arts (2004b).

Baron, Beth. Egypt as a Woman: Nationalism, Gender, and Politics. Cairo: American University in Cairo Press, 2005.

Billig, Michael. Banal Nationalism. London: Sage, 1995.

Brunn, Stanley D. "Stamps as iconography: Celebrating the independence of new European and Central Asian states." GeoJournal 52, no. 4 (2001): 315 - 323.

Cerulo, Karen. Identity Designs: The sights and sounds of a nation. Brunswick, NJ: Rutgers University Press, 1995.

Child, Jack. "The Politics and Semiotics of the Smallest Icons of Popular Culture: Latin American Postage Stamps." Latin American Research Review 40, no. 1 (2005): 108-137.

Cusack, Igor. "Nationalism and the colonial imprint: The stamps of Portugal and Lusohpone Africa and Asia." (2003).

Delobsom, Dim. L'empire du Mogho-Naba. Paris: Domat-Montchrestien, 1932.

Hourani, Albert. Arabic Thought in the Liberal Age, 1798-1939. Cambridge: Cambridge University Press, 1983.

Jones, Robert A. "Science in National Cultures: The Message of Postage Stamps." Public Understanding of Science (2004): 75-81.

Lauritzen, Frederick. "Propaganda art in the postage stamps of the Third Reich." Journal of Decorative Propaganda and Arts (1988): 62-79.

Levin, Jessica. "Sculpted Posts: Architectural Decoration on Gabonese Stamps." African Arts (2004).

McCrone, David. The Sociology of Nationalism. London: Routledge, 1998.

McQueen, Humphrey. "The Australian stamp: image, design and ideology." Arena 84 (1988): 78-96. 
Mwangi, W. "The Lion, the Native, and the Coffee Plant: Political Imagery and the Ambiguous Art of Currency Design in Colonial Kenya." Geopolitics 7, no. 1 (2002): 31-62.

Newman, R.S. "Orientalism for Kids: Postage Stamps and "Creating" South Asia." Journal of Developing Societies 5 (1989): 70-82.

O'Sullivan, Charles J. "Impressions of Irish and South African national identity on government issued postage stamps." Eire-Ireland 23 (1988): 104-15.

Posnansky, Merrick. "Propaganda for the millions: images from Africa." African Arts (2004).

Raento, Pauliina, and Stanley D. Brunn. "Visualizing Finland: Postage Stamps As Political Messengers." Geografiska Annaler Series B: Human Geography 87, no. 2 (2005): 14564.

Reid, Donald M. "The symbolism of postage stamps: a source for the historian." Journal of Contemporary History 19, no. 2 (1984): 223-49.

Scott, David. "National icons: the semiotics of the French stamp." French Cultural Studies 3, no. 9 (1992): 215-34.

Scott, David. European Stamp Design: A Semiotic Approach to Designing Messages. London: Academy Editions, 1995. 
Figure 1: Average number of stamps issued per year, 1960-2003

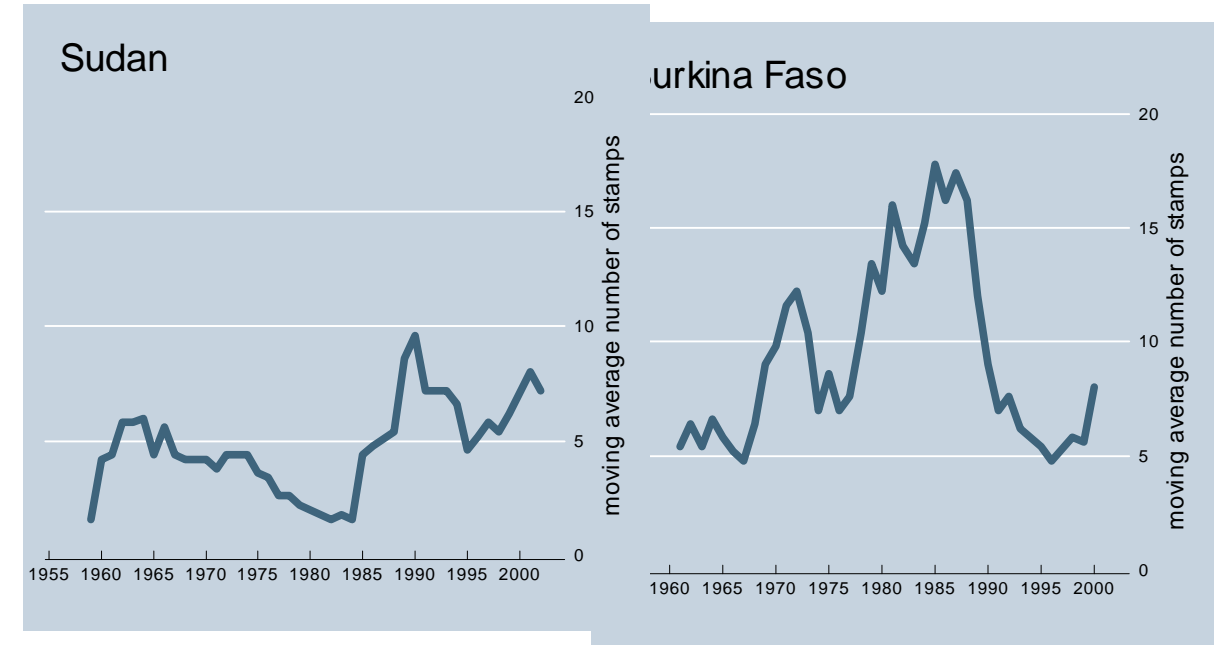


Figure 2: Trends in percent of postage stamps in broad categories across regimes

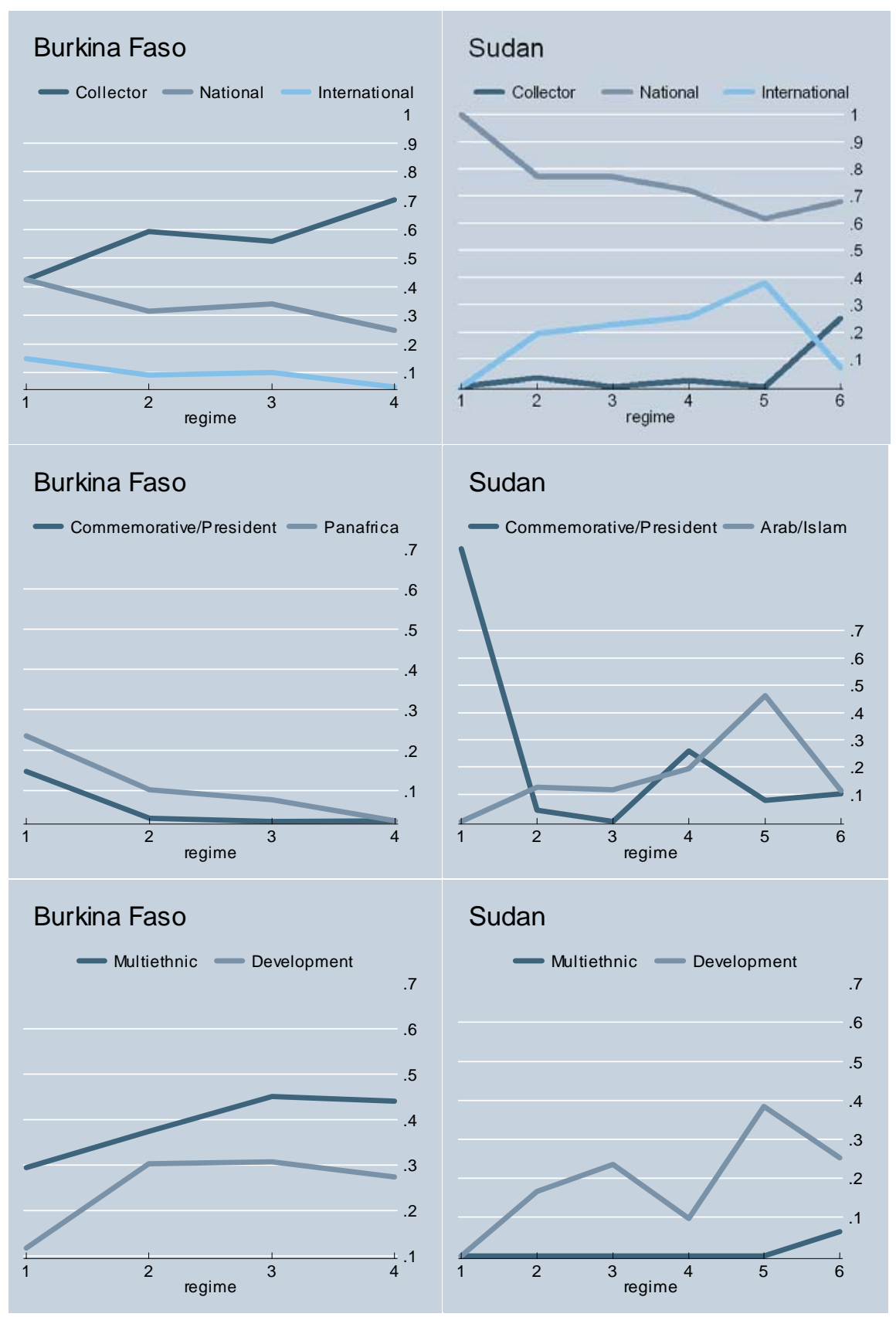

Note: Regimes for Burkina Faso are: (1) 1960-66, Yaméogo civilian regime; (2) 1966-80, Lamizana military regime; \{3\} 1980-87, Transition and Sankara military regime; (4) 1987-2003, Compaoré military regime. Regimes for Sudan are: (1) 1956-58, 1st democracy; (2) 1958-64, Abboud military regime; (3) 1964-69, 2nd democracy; (4) 1969-85, Nimeiri military regime; (5) 1985-89, 3rd democracy; (6) 1989-2003, al-Beshir military regime. Figure 2: Percent of images in major categories of national-oriented stamps, for different political regimes 
Figure 3: Radar graphs of proportion of stamps in different categories for different regimes
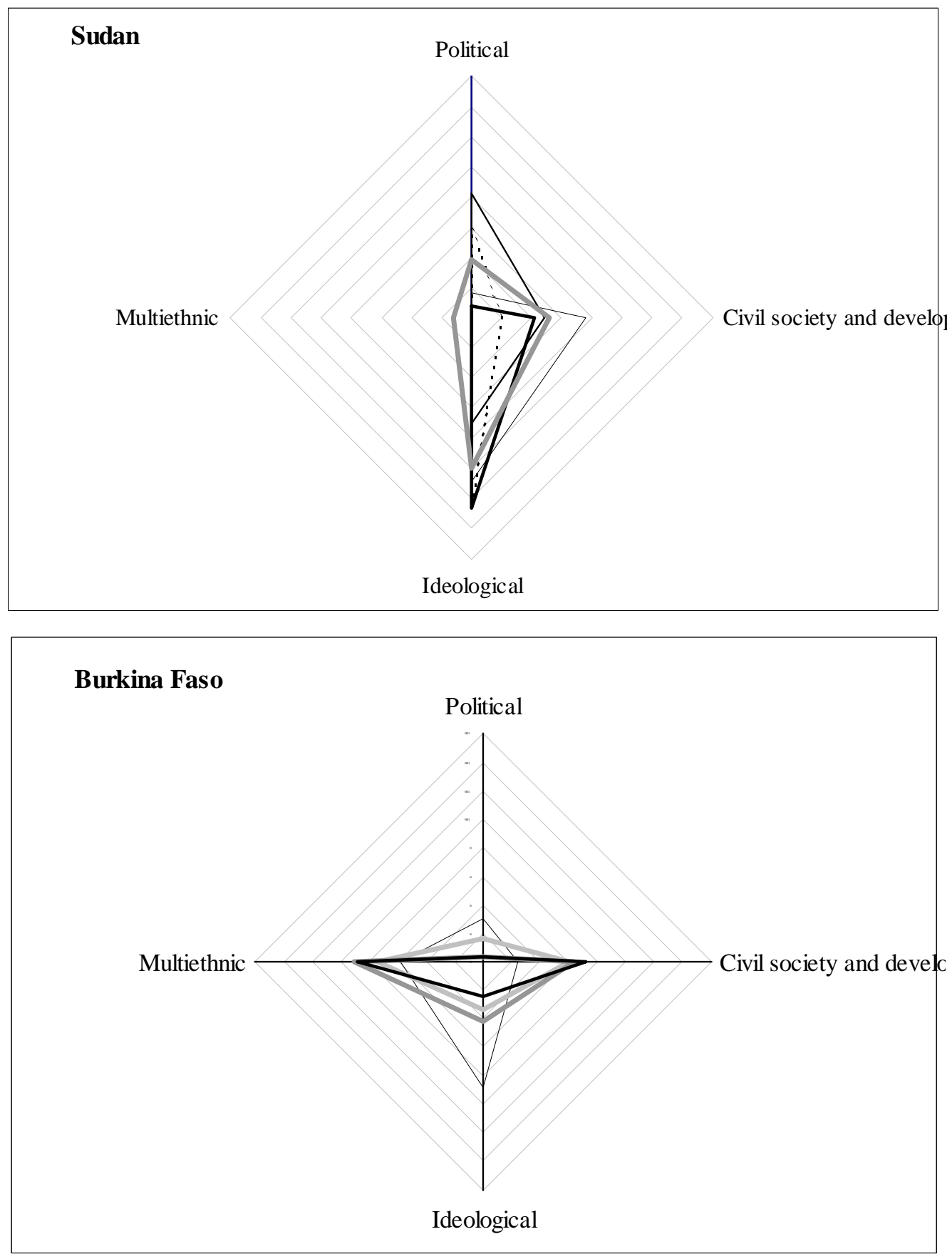

Note: Regimes for Burkina Faso are: (1) 1960-66, Yaméogo civilian regime; (2) 1966-80, Lamizana military regime; \{3\} 1980-87, Transition and Sankara military regime; (4) 1987-2003, Compaoré military regime. Regimes for Sudan are: (1) 1956-58, 1st democracy; (2) 1958-64, Abboud military regime; (3) 1964-69, 2nd democracy; (4) 1969-85, Nimeiri military regime; (5) 1985-89, 3rd democracy; (6) 1989-2003, al-Beshir military regime. 
Table 1: Categories of stamps coded for Burkina Faso and Sudan: Definitions and Frequencies

\begin{tabular}{|c|c|c|c|c|c|}
\hline & \multicolumn{2}{|c|}{ Burkina Faso } & \multicolumn{2}{|c|}{ Sudan } & Definition (what is major image, raison d'etre, or text on stamp) \\
\hline Category & $\begin{array}{c}\text { Number of } \\
\text { stamps } \\
(1956 / 60- \\
2003)\end{array}$ & $\begin{array}{c}\text { Percent of } \\
\text { all stamps } \\
(1956 / 60- \\
2003)\end{array}$ & $\begin{array}{c}\text { Number } \\
\text { of } \\
\text { stamps } \\
(1956 / 60 \\
\text {-2003) }\end{array}$ & $\begin{array}{c}\text { Percent of } \\
\text { all stamps } \\
(1956 / 60- \\
2003)\end{array}$ & \\
\hline
\end{tabular}

(a) Broad categories

\begin{tabular}{|c|c|c|c|c|c|}
\hline $\begin{array}{c}\text { Collector's items for philatelic } \\
\text { market }\end{array}$ & 608 & $61 \%$ & 31 & $13 \%$ & $\begin{array}{l}\text { Intended for collector's market (e.g. Lady Di) and stamps of local flora and fauna with no obvious } \\
\text { nationalism message (e.g. butterflies, tropical fish) }\end{array}$ \\
\hline International & 85 & $8 \%$ & 38 & $16 \%$ & $\begin{array}{l}\text { International organizations or international coordination (e.g. Year of the Child, World Meteorological } \\
\text { Union) }\end{array}$ \\
\hline National-oriented & 308 & $31 \%$ & 166 & $71 \%$ & Promote imagery of national identity \\
\hline Total & 1001 & & 235 & & \\
\hline
\end{tabular}

(b) Breakdown for national-oriented stamps only

\begin{tabular}{|c|c|c|c|}
\hline Christianity & $0 \%$ & $0 \%$ & $\begin{array}{l}\text { Overtly Christian icons or persons, except for Christmas stamps, and except as part of series representing } \\
\text { other persons or icons; pictures of the Pope counted only if in honor of Papal visit. }\end{array}$ \\
\hline Colonial power & $2 \%$ & $0 \%$ & $\begin{array}{l}\text { Honor, in a sycophantic way, a colonial or other power (e.g., stamps honoring de Gaulle, or state visits by } \\
\text { the British Queen) }\end{array}$ \\
\hline $\begin{array}{l}\text { Commemoratives and } \\
\text { political }\end{array}$ & $2 \%$ & $11 \%$ & $\begin{array}{l}\text { Events important in national history (e.g. independence anniversaries, coups, regime transitions, regime } \\
\text { anniversaries) or important political events (Party Congress, for example, in single-party states) }\end{array}$ \\
\hline Development & $28 \%$ & $22 \%$ & Economic development (projects, modern agriculture, industry, buildings, public services, education) \\
\hline Ethnic & $0 \%$ & $2 \%$ & $\begin{array}{l}\text { One particular ethnicity or group of ethnicities at the expense of other ethnicities (so typically a series of } \\
\text { stamps showing local culture of one group, but not showing other cultures, and no series within two years } \\
\text { shows those other cultures- e.g. multi-cultural not spread out) }\end{array}$ \\
\hline Icons & $11 \%$ & $27 \%$ & $\begin{array}{l}\text { Images of the nation (antiquities, monuments, natural wonders, flags, traditional life, prehistory, historical } \\
\text { events, coats of arms, etc.) }\end{array}$ \\
\hline Multi-ethnic & $41 \%$ & $3 \%$ & $\begin{array}{l}\text { Multiple ethnic or religious groups; usually a series of stamps showing local culture or traditional } \\
\text { institutions where there is a clear attempt to represent a broad cross-section of ethnicities or religions; or } \\
\text { stamps explicitly advocating tolerance }\end{array}$ \\
\hline Political person & $2 \%$ & $7 \%$ & Political personage from the country (most are deceased) \\
\hline Non-political person & $3 \%$ & $0 \%$ & Sports figures, artists, writers, etc. from the country (often still living) \\
\hline PanAfrican & $9 \%$ & $11 \%$ & $\begin{array}{l}\text { PanAfrican institutions or ideals, or that honor African leaders from other countries (e.g., Organization of } \\
\text { African Unity, Africa Cup) }\end{array}$ \\
\hline PanArab/PanMuslim & $0 \%$ & $16 \%$ & $\begin{array}{l}\text { PanArab or Muslim institutions or ideals, or that honor Arab leaders from other countries or that have } \\
\text { Islam as the central idea of the stamp (e.g., a mosque, not part of a series of multifaith stamps) }\end{array}$ \\
\hline Presidents & $2 \%$ & $1 \%$ & Current President or national leader \\
\hline Women & $0 \%$ & $1 \%$ & Named women, women’s organizations, or women’s empowerment. \\
\hline
\end{tabular}


Appendix: Select images of postage stamps from Sudan and Burkina Faso

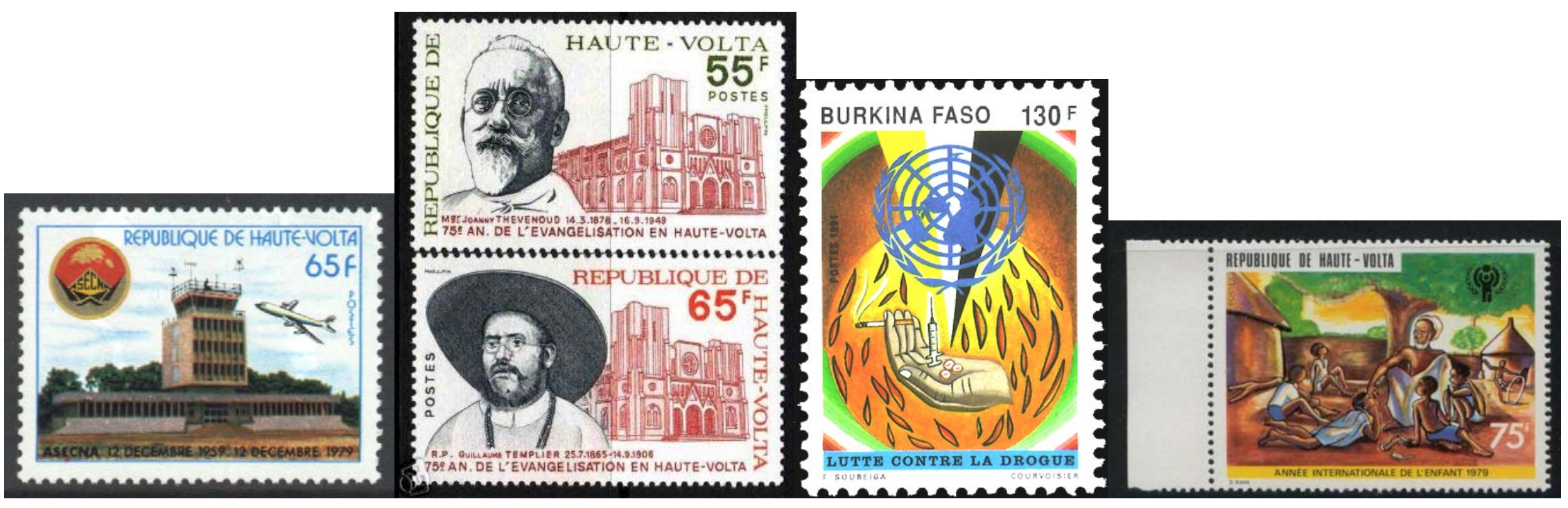



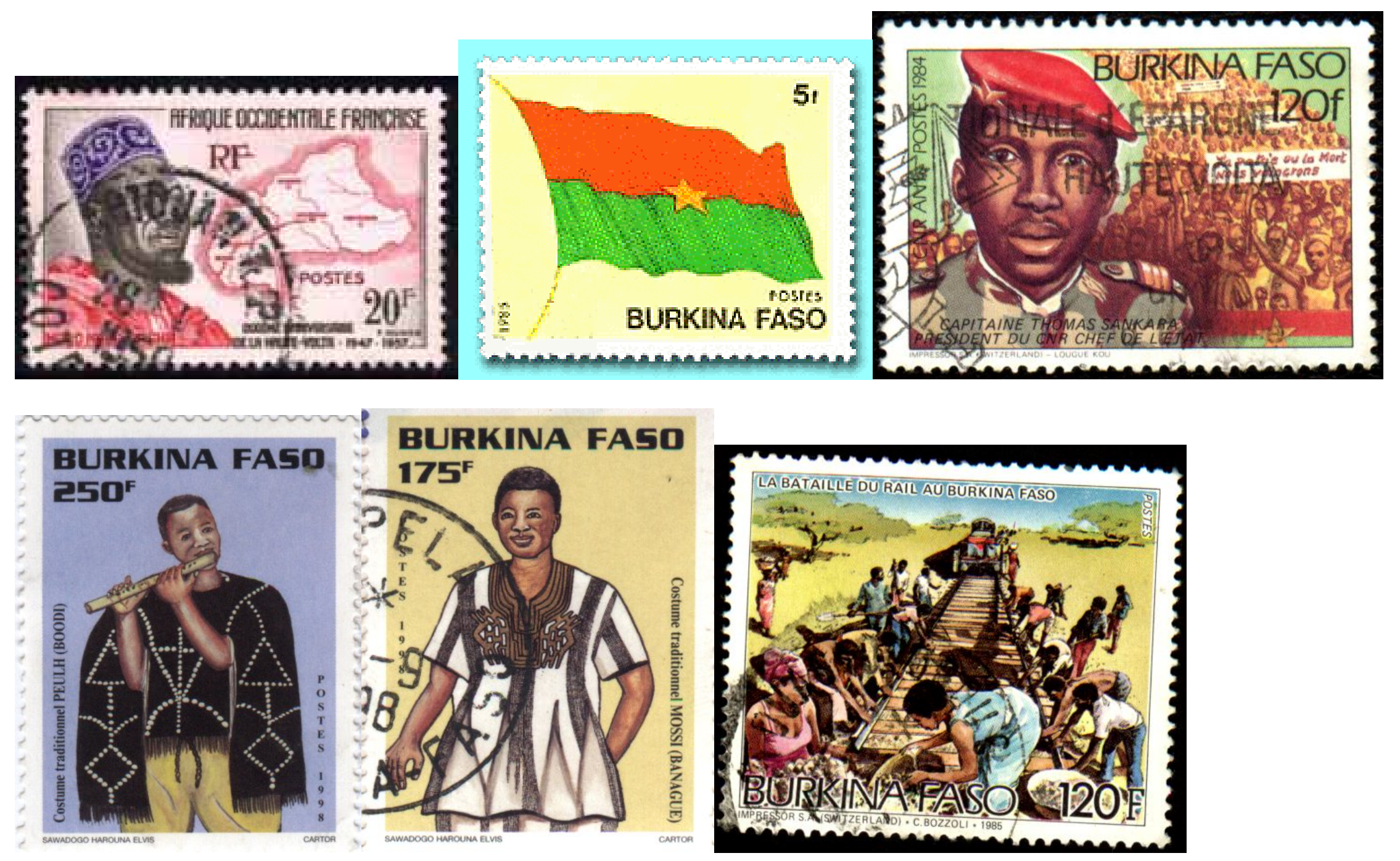

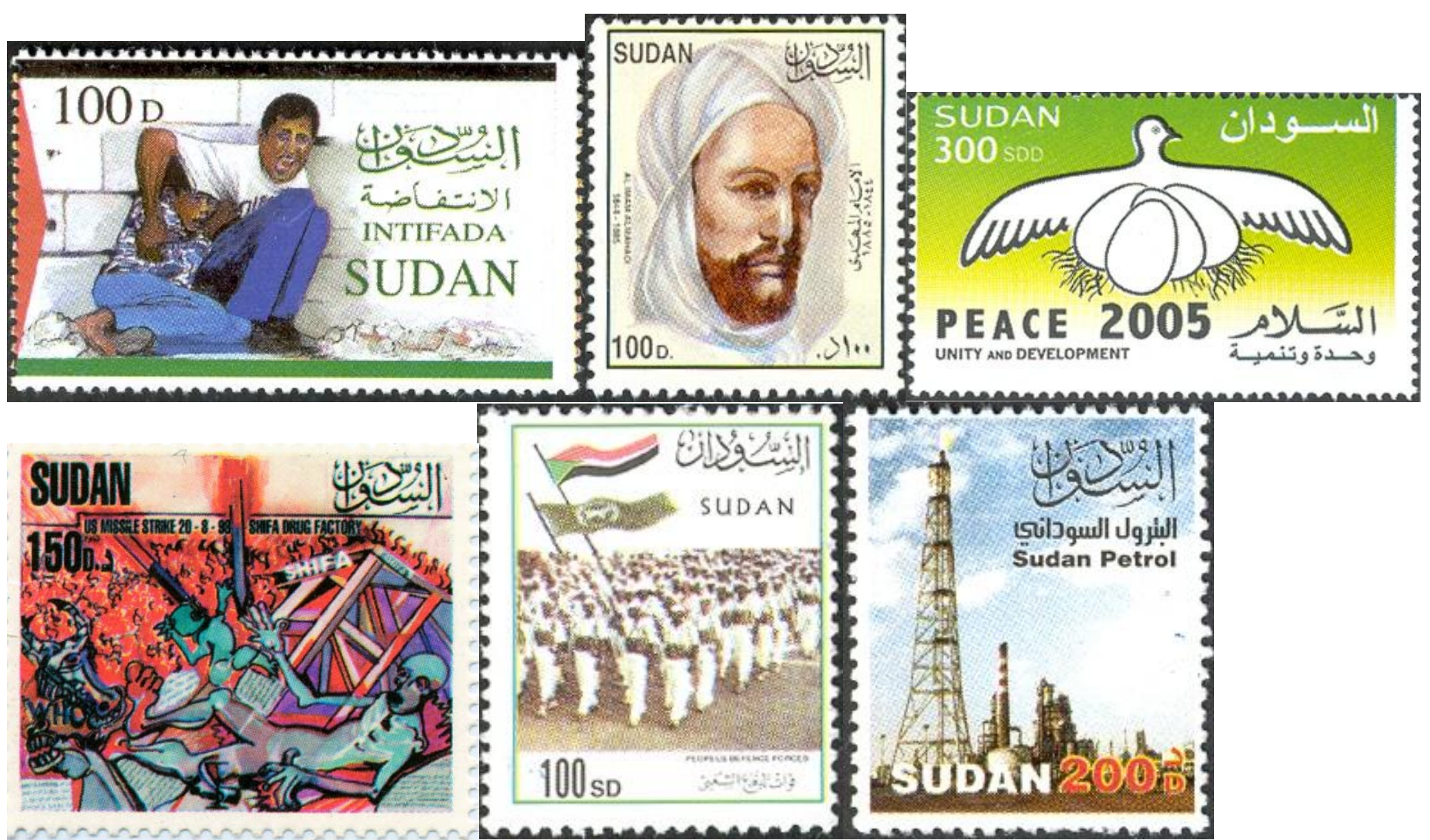

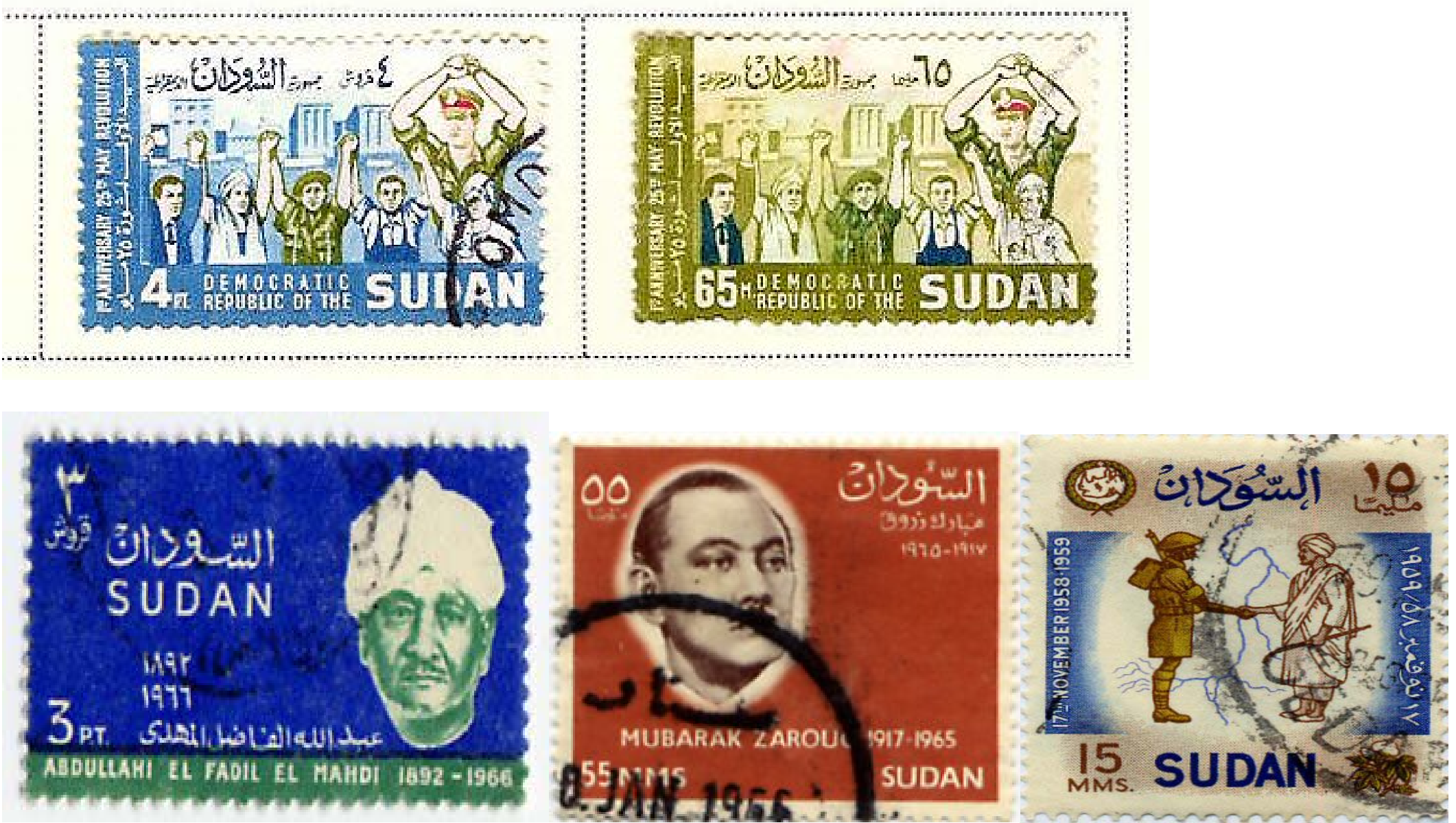